\title{
CAPITALISM IN EARLY MODERN EUROPE
}

An old debate in economic history is revived in Failed Transitions to Modem Industrial Society: Renaissance. Italy and Seventeenth Century Holland. Proceedings of the First International Colloquium. April 18-20. 1974. Interuniversity Centre for European Studies, ed. Frederick Krantz \& Paul M. Hohenberg (Montreal Interuniversity Centre for European Studies. 1975). These exchanges, the editors affirm. were meant to show the historical consequences and specific effects of successive stages of industrial leadership. But the focus on concrete cases translates here as a retreat from precisely the ground where historians can be uniquely useful: systematic consideration of the mechanisms of uneven development. Failed Transitions fails to show how structural inequalities between labor and capital can sometimes brake the development of human and material resources.

Symptomatically, the substance of the conference title was rendered quite differently in the two official languages. Some participants even suspected they were talking about a pseudoproblem, or one carrying irrelevant connotations of moral degeneracy. No one thought to rephrase the vexing question so as to ask: "Whom Did the Transition Fail?"

What may have been gained or lost by Italian or Dutch people in the course of industrialization was an issue never directly confronted. Prof. R. Brenner reminded the closing session that industrialization was paid for by a rural population with a key role in class relationships, and Prof. J.A. Smit questioned the conventional view of a Holland free of poverty. but the majority of discussants forgot that the essence of the process was its mass character. If labor emerged as a dominant issue, it did so painfully and in terms only of labor's passive utility for other factors of production, even thought the historic transition to a passive role is precisely the issue. Did successful resistance to the 17th century ribbon loom in northern Europe (precursor to the power loom) depend, as Karl Marx suggested, on the distinction he thought fundamental between simple machines, still incorporating primarily human labor power, and complex tools?' What was the situation in Italy and Holland?

If labor as an agent with its own energies, weaknesses and problems of political direction and communication remained invisible in the drama, or else hovered, a mute abstraction, in the wings, the relation between its diet and industrialization ${ }^{2}$ was not raised either-not even as part of a general theory of consumer demand. But in the almost total neglect of population factors at Montreal. the omission is hardly surprising. It seems odd to ignore controversy over the demand schedule for labor. or over the weight to be given to forces acting on population other than those working directly on births and deaths. ${ }^{3}$ Evidence for Italy and Holland may not be abundant or precise. and the incidence of subsistence crises may not be what distinguishes an industrializing country from a "failure." but the size and sex composition of a population do affect the size of the labor pool available for industry.

Needless to add, the assembly of scholars never once considered the consequences of that specifically sex-based form of labor power that industrialization initially seems to require. There was no discussion of the sex-related wage differentials conveniently and artificially maintained by social conditioning and by political pressures. Thus, if the general ratio of female to male wages helped to support a low general wage level and an unemployed labor pool in a "successful" 
country, this in turn depended on the degree of political centralization attained. Sex differentials were reinforced by a progressively codified law. Was it in these respects that Italy and Holland "failed"?

Nor did anyone ask in which decades and to what degree the so-called "European" marriage pattern affected the size of the female labor force in those regions. And not a word was exchanged about the role of the family wage system in reducing the worst effects of subsistence crises and recurrent industrial layoffs. The situation in both Italy and Holland has been little studied and would reward attention."

This is not to say that the colloquium raised no new issues. (Indeed. it avoided well-beaten paths, such as the formation of credit institutions. that in the case of Italy-perhaps also of Holland-might usefully be retrod.) In its eagerness for fresh and multidisciplinary viewpoints the conference sparked spontaneous and often vivid insights. The volume of Proceedings is indeed the "rich mix" praised by its editors, whose admirably precise guide to the mixture makes up in zest and texture what the rest of the pudding lacks. And it is fortified by an equally nourishing bibliography. But the accurate and specialized knowledge of participants could have been put to much better use. and made more accessible to the general reader.

The specialists made no attempt to muster the full array of potential data and explanatory concepts needed to make sense of an issue too complex to be resolved by additive explanations. The pursuit of novel phenomena regardless of the scale of their effects was a characteristic flaw of the Montreal debates. Good questions on the Italian case were trivialized by association with others of unknown or suspect statistical significance: the southward flow of Florentine wool; the export of olive oil: stunted factory-style production in Venetian mills and glassworks; the state of experimental and abstract sciences in an underestimated Italian Enlightenment-issues all distracting from more fundamental questions: under what circumstances sharecropping in Tuscany and Milan really fostered capital accumulation? What economic realities underlay an apparently political failure to back free trade?

The barrage of perceptive comments in the Proceedings seems patternless. It remains a useful handbook for the archivist shopping for topics. We are made aware of a mass of still undigested archival material, as yet inaccessible to all but a handful of researchers. But little attempt has been made to bring topics and material into some kind of relationship with each other. And so much disagreement over fact, let alone over interpretation. especially in a climate of coyness about the very word "capitalism," limits the value of the symposium as a new venture in explaining industrial revolution. Yet the diligent reader still may track a path.

The editors point to four major sets of tension pervading the debates: disputes about the meaning of transition; competing emphasis on commerce and exchange as opposed to the role of agriculture; disagreement as to the weight to be allowed to the internal responses of relatively autonomous societies to movements of transcendent magnitude; and finally, two distinct ways of viewing money-as a means of capital accumulation and as a means of exchange. To hose at once perceiving such tensions to be needless. I must point out also that the concept of a set of social relations of production had repeatedly to be vindicated as the only substantial defense against the grosser sort of economic determinism, for which Marxist speakers were the least responsible. 
Unwillingness to work with the concepts of political economy instead of economies was a major reason why it took the academicians so long to conclude that the two cases under review embodied two distinct kinds of "transition." Despite the heat generated around this word, it was not until the eleventh hour that any definition was offered. Profs. A. Dubuc and I. Wallerstein explained that two distinct transitional phases could be discerned: an early, basic shift away from a "feudal" mode of production. in which all regions participated to some degree; followed by industrialization proper. where capital was geared to industry rather than to agriculture-a transition occurring only once. in England between the 1760s and the 1830s. Italy and Holland each in turn provided leadership in the primary transition. Furthermore, each successive "core" region, in either phase of transition. passed through successive employment levels, tied to subsistence in distinct ways. The "lead" country is always the one with a medium wage level and a relatively liberal structure combining internal freedoms with the ability to maneuver its social groups without excessive military and taxation costs. In decline, the wage level is too high for competitive production in the available markets. From 1650 to 1750 , Europe as a whole passed through such a "phase B." although the contraction process was uneven. Loss of lead by the Italian regions was followed by a fight between their potential successors, England and Holland. As Holland emerged victorious at this stage, England and France went on to vie for first place in the next round.

This by now familiar thesis ${ }^{3}$ bounds into the final sequences of the Montreal scenario with all the finess of a deus ex machina. The floundering and disheartened protagonists are rescued in an operation timed either ludicrously ill or cunningly well. It is hard to decide which, for the very tensions inherent in the debates often do point in the appropriate directions.

A heavy emphasis on the roll of international trade tended to stress political response to external forces, with "failure" implying policies that were too strictly local or regional. The distinctiveness of Dutch and British imperialism was contrasted with that of Spain and France, those other trading colonizers. Still, no-one plainly asked when, by whom and how the new role for commerce was assumed that is implicit in the distinction between trade and capital as Marx defined it. (Exchange in what he called its "normal" form. whether money is used or not, is not the "value in process" which can "add value" and become capital in the strict sense.) 6 Since the real question. then, was how exactly to define the international trade of Italy and Holland, the lengthy exchanges on the nature and patterns of such trade did indeed verge on explaining as much about contraction in Italy's phase B as discussions about the scale of production may have done in regard to Holland's leadership phase. International trade was, in fact, the arena in which Marxists and non-Marxists clashed most openly, not only because of this unarticulated issue. but also because the underlying structures of foreign commerce have much to do with the formation of adequate markets.

The process of class formation and its implicit antagonisms then moved with relentless logic into the foreground of debate. Evidently "transition" is unlikely where the retarded breakdown of older structures holds up the proper class formation. A political elite may have liquid capital while fixed productive assets remain in the hands of one or more different social groups. ${ }^{7}$ Or, groups with similar production relations may not always and simultaneously perceive. much less act in. their mutual interests. These issues were touched upon but their significance was not 
elaborated. For the Italian case. Prof. Procacci (in a post-conference communication) was obliged to explain how the concept of "refeudalization" had been misconstrued. For Holland. Prof. K.W. Swart's "aristocratization" or "de-proletarianization" stimulated extensive comment. Yet for both regions. the question of "class balance" was raised almost inadvertently, as inflexibility in the face of external pressures was attributed to a motionless or balanced economy. The intriguing situation of Genoa just missed putting the problem of uneven development into the clearest possible perspective. Evidently Genoese capital. as Prof. S. Berner related, was responsive to environmental need. But this cosmopolitan society remained myopically conservative in its political life. Were city-type, ethnology, or the idiosyncracies of the majority of Genoese themselves responsible? While sporadic references to a vaguely conceived role of "mentalities" were understandably brushed aside during the conference. it could usefully have discussed the bio-social-historical matrix which prepares an entrepreneurial society-a matrix in which the behavior of the working majority is an essential vector.

It was high wages and production costs that elicited the lengthiest and most confusing exchanges. The sharpest altercation occurred, amid a weiter of often contradictory detail about productivity, trade and taxes. as Profs. D. Sella and Berner disagreed over the possibility that a rise in subsistence wages-perhaps occasioned by a rise in grain prices-kept real costs of production high in Italy, even before the advent of northern competition. Where and when the latter began proved uncertain. due to a dearth of evidence on ports other than London; on types of cloth other than shortcloth, and so forth. Data on the level of real wages in gild structures, and their effects on capital accumulation, were equally inconclusive. The picture of alternative investments remains too shadowy. Discussants disagreed over whether they should be talking about a margin above subsistence, or about unit labor costs. Prof. Sella suggested that by mid-17th century, the living standards of workers had risen, but that "the commodity equivalent of wages" still had not changed substantially. However, profits were being squeezed by plummeting prices. It was not then, after all, so much a matter of high productions costs or rigid gild regulation, as of how well the newly developing mode of production was allowing those with control of resources to absorb the labor of others. Perhaps the crucial step in transition is not so much the relaxing of restrictions on wages as the limitation of apprenticeship. blocking off one of the broader access roads to the new role of "capitalist."

The Dutch case finally seemed to convince participants that relative, not absolute decline was the proper way to discuss transition; that by the 18th century there was no longer any question of an overall retreat across Europe of the newer mode of production. The history of Italy between the 15th and the 17th centuries, on the other hand, does seem to imply something of the kind. But in debating the Dutch case. "sustained growth" was being distinguished from industrialization proper, based on a transformed agriculture, on factory production and on the resolution of specific class tensions. While the former might depend more on the interplay of market forces than on anything else, the latter certainly could not.

All the same, participants seemed reluctant to commit themselves on the state of Dutch industries. or to a view that Dutch prosperity was principally commercial still, based on speculation and overseas ventures that were not quite broad enough to form the base of 
industrialization proper. Prof. D. Ormrod's impressive and ingeniously documented work on the grain trade and on Dutch linen and paper making industries is technically the best piece in the collection. but his focus on protectionist policies lacked all reference to internal structures and to relationships between the factors of production. The incapacity of industries to respond to a new situation still was not explained. The criticisms of Profs. J. de Vries and Smit tended to restore the tenor of debate to one involving the whole set of production relations, specifically, those of a static, over-urbanized society with a very specialized agriculture and lacking a true proletariat. Early modernization can actually be a barrier to later industrialization. And the role of military power can be crucial.

It looks as if contributors were not clearly told the precise nature of their role or the conference topic. Yet the Wallerstein framework could and should have evolved gracefully from a well conceived program of debate, and if this seemed problematic, then the key hypotheses ought to have been laid before the assembled specialists for their appraisal. fair and square. Billing the star performance to follow a completely unrehearsed corps de ballet may have avoided disrespect for the principles of free-wheeling enquiry, but it was inept choreography.

The ensuing collection of partial data and eclectic opinion, however interesting. persuades the reader only of an urgent need not just for much more information but for a common language of generalization among social historians and a shared statistical sense, if nothing more. Random responses offered no substitute for what was implicitly rejected or ignored.

Where the underlying factors in the transition to modern industrial society are still in question. they should be sought, as far as possible. with the tools of multivariate analysis, subject to an agreed process of testing and review. For the most part, however, such factors are surely the components of that very "capitalism" whose definition everyone was at such pains to avoid. And by default, the conference acknowledged that a Marxian analysis is still the only game in town.

\section{Kathleen Casey \\ Sarah Lawrence College}

1. Karl Marx. Capiral (New York: International Publishers, 1967), vol. 1, pp. 367-68, 371-78, 428.

2. See. e.g., Elborg and Robert Forster, eds., European Diet from pre-Industrial to Modern Times (New York: Harper Torchbooks. 1975).

3. E.g.. T. H. Marshall. "The Population Problem during the Industrial Revolution: A Note on the Present State of the Controversy." in D.C. Glass and D.E.C. Eversley, eds., Population in History (Chicago: Aldine Press. 1965).

4. Isolated studies on contrasting regions of Italy suggest what these patterns might be: e.g., E. Todd. "Mobilité geógraphique et cycle de vie en artois et en toscane au XVIIle siécle," Annales. E.S.C. 30:4 (July-Aug. 1975).

5. I. Wallerstein. The Modern World S!stem: Capitalist Agriculture \& the Origins of the European World-Economy in the 16th c. (New York: Academic Press. 1974).

6. Marx, Capital, vol. 1. pp. 146. 153-154, 160.

7. Rubert DuPlessis. "Class Consciousness in Western European Cities, 1400-1050." Radicai History Review 3:1.2 (Fall-Winter 1975). An ethnological approach to location of industry may be found in René Maunier. LO Origine et la fonction économique des ville études de morphologie sociale (Paris: V. Giard \& E. Briere, 1910). 